\title{
Mantra for Health in The Slope of Mount Merapi- Merbabu: Changes and Challenges
}

\author{
K P Kusciati ${ }^{1}$, S T Widodo ${ }^{2}$, T Widyastuti ${ }^{3}$ \\ \{1karunia.purna@staff.uns.ac.id, ${ }^{2}$ sahidteguhwidodo@yahoo.com, ${ }^{3}$ theresia.widiastuti@yahoo.co.id\} \\ 1,2,3 Universitas Sebelas Maret
}

\begin{abstract}
Mantra as a form of Javanese oral tradition has been practiced in District Sawangan, Magelang Regency for a long time. Mantra which gives magical power to those who recite it plays an important role in the life of the people living in this slope of Mt. Merapi-Merbabu area. One of mantras that has been practiced and used the most is those relating with health. Many of the inhabitants are still found seeking dhukun for curing their illnesses. The factors of them still practicing mantra can be divided into two, namely geographical and social-cultural condition. However, as the fast paced changes happen does it influence the practice of mantra for health? Therefore, this study aims to describe how the practice of medical treatment using mantra in Sawangan District, Magelang Regency facing the challenges resulting from the fast paced changes. Since this study is a qualitative descriptive one the data are in the form of words both in the written and oral forms. To gather the data the direct observation and interview were conducted by using purposive sampling. The results of this study show that a form of cultural compromise with the influence of Islamic teaching occurs in mantra for health. Meanwhile, the dhukun answers the challenge of "modern" illnesses by rationalizing and making sense the mantra with the knowledge.
\end{abstract}

Keywords: Mantra, Health, Challenges, Changes, Sawangan District, Mt. Merapi, and Mt. Merbabu

\section{Introduction}

Sawangan District is one of the districts in Magelang Regency which is located in the slope of Mount Merapi and Merbabu. Becoming a district which is rich with the ancient heritages, people in this area still recite mantra in their daily life. Mantra is one of forms of Javanese oral tradition. The word mantra comes from Sanskirt which means "protecting one's mind from low worldly passions" [1]. It also means japa (the words which are spoken repeatedly by moving the lips but without making any sounds) [2]. Indeed mantra is usually recited repeatedly and is believed to have magical powers [3][4]. Mantra itself has various types such as mantra for attracting opposite sex, mantra used in some ritual during farming, mantra for attracting customers to buy the sellers' goods, mantra for obtaining a strong body that will not easily hurt by any weapons, mantra for medical purposes, etc [2]. It can be seen that mantra is used or recited in certain time and place to get certain purposes for those who 
recite or practice it. Not everyone is able to master or use mantra. Those who have high spiritual and supra natural ability usually are the ones who can master it, such as kyai or dhukun [5]. The tradition of traditional medical treatment accompanied by the reciting of mantra is the one commonly found in Sawangan District, Magelang Regency.

There are some factors that influence the people in Sawangan District still practice reciting mantras for their health, namely the geographical and social-cultural conditions of the people. Most of the population in that area work as farmers who plant chilies, tomatoes, potatoes, carrots, cabbages, mustard greens, beans, etc because of their rich nature with its fertile soil. With its cool air and beautiful natural scenery, this region then develops into an agrotourism area. One of the famous tourism objects, Ketep Pass, is visited by many tourists who want to enjoy Mount Merapi view in its viewing post. Several new attractions which offer the best selfie spots have also mushroomed. The contour of the winding land with steep slopes is the main attraction to reach these tourism objects. The main road is paved but rural roads are still in the form of cement roads or stone paths which are arranged neatly. Facilities in this region are quite adequate such as schools from kindergarten to high school/vocational school, markets, and public health centers [6].

Community life is fairly harmonious with the tradition of mutual cooperation. Most of the population are Muslim but traces of Hindu-Buddhist beliefs are still found. HinduBuddhist relics in the form of terraces (punden) are indeed found in several places in this region [6]. Therefore, it is not surprising that the influence of Hindu-Buddhist religion is still visible, for example in folk art, namely Jathilan, Jalantur, Kobra Siswa, and Topeng Ireng who present "possessions" or ndadi as the climax of the show. The ritual of being possessed or ndadi is an example of Hindu elements in the Javanese tradition [7]. Mantra itself is also a form of Hindu-Buddhist heritage. Mantra is included in the speech text which is the religious speculation of Shivaistic and Buddhist on old Javanese texts [8].

There are four elements in traditional medical treatment using mantra. They are dhukun, the ones who recite mantra and treat the patients; sesaji/sajen, offerings used in treatment; traditional herbs as medicine; mantra itself. Dhukun is usually a person who has high spirituality and is able to face any supra natural challenges or nuisances. In treating some diseases a dhukun needs to undergo some rituals before treating a patient, for example having a fasting in certain amount of time. Dhukun also uses some media to treat the patients such as a glass of water in which he recites mantra to it and sometimes asks patients to repeat after him then asks the patients to drink that glass of water.

Based on the description above it is quite clear that the mantra becomes an inseparable part of the daily life of the people of Sawangan District, Magelang Regency who live in the slope of Mount Merapi-Merbabu. However, along with the fast paced changing of times and development especially in communication and technology is the practice of medical treatment with mantra recitation still somewhat relevant? How do practitioners of mantra answer the "challenges" resulting from those changes?

\section{Research Method}

The purpose of this study is to describe how the practice of medical treatment using mantra in Sawangan District, Magelang Regency facing the challenges resulting from the fast paced changes. Thus, this study can be categorized as a descriptive qualitative study. Qualitative study is in the form of "meanings, concepts, definitions, characteristics, metaphors, symbols, 
and descriptions of things" [9]. Therefore, descriptive qualitative study interprets the data in its analysis [10]. The data of this study were gathered by conducting a deep interview to some people living in Sawangan District who practice medical treatment using mantra that were chosen purposefully. Therefore, the informants were dhukuns, patients, and local inhabitants. Besides interviewing the informants, observation of how the mantra for medical purposes were practiced and the inhabitants life in the area was also conducted. The interactive work method of three components was applied in analyzing the data. Those three components are data reduction, data presentation, and data verification [11]. First, the data from deep interview and observation were collected by recording, noting down, and transcribing. They then displayed based on the characteristics of the research problem. Lastly, some conclusions as the result of analyzing the data were drawn.

\section{Results And Discussion}

Mantra for health treatment is found in the Merapi-Merbabu manuscript collections. The collections come with many kinds of form: kakawin, parwa, primbon, and mantra. The manuscripts are written on the palm leaf and uses the Buda script. Most of them are written in Javanese script but few of them are in Arabic. Some mantra manuscripts are found in the medicine manuscripts. However, some of them are written specifically about mantra only. It can be seen that the mantra for health becomes an important part of the Merapi-Merbabu manuscript collections and has existed since ancient times [8].

The ancient Merapi-Merbabu manuscript collections are one of the relics of HinduBuddhist beliefs. Hindu-Buddhist influence indeed still plays a significant role on the people's life in the slope of Mt. Merapi-Merbabu. Traditional ceremonies and rituals in that area are still seen and practiced. For example there are many cultural heritages and ritual ceremonies which are still held in certain places that are considered sacred and have magical powers.

However, along with the coming of Islam in the 18th century, Hindu-Buddhist influences began to erode even though traces of Hindu-Buddhist beliefs are still visible, for example the appearance of the santri abangan. These people are referred to as people whose Islam is stopped in their appearance only. The emergence of santri abangan are not seen as a struggle between local (Javanese) and foreign (Islam) cultures but as a phenomenon of Islamization that continues to develop. This phenomenon appears in the "slametan" ritual which is held by the abangan but led by the santri [7].

As the understanding of Islamic belief getting better it cannot be denied that there are some Muslim who consider the practice of medical treatment accompanied with mantra recitation is categorized as syirik (an act in which believing in another power other than God [Allah SWT]). They argue that Muslim should pray directly to Allah SWT and mentioning Allah SWT properly of course in the form of Islamic prayers that have been taught by prophet Muhammad SAW. However, there are still some of Muslim who are not against mantra and even still practice it. They argue that if it is needed, it is fine to use mantra or to practice it. Mantra itself in its development after the coming of Islam has Islamic influences, for example most of mantra start with Bismillahirohmanirohim and mentioning Allah. The coming of Islam apparently did not automatically change the beliefs once existed before. Below are the example of some mantras 
Mantra for fever Assalamuallaiykum (3x) / Angin Allah kang ana sirah, metua / Yen ora metu kena dukane Allah (3x) [2]

Mantra for stomachache Bismillahirohmanirohim / Mbok ibu bumi / aku njaluk tamba lara weteng / Kang bapa kuwasa / Aku njaluk tamba lara weteng / Tamba teka lara lunga [2]

In those mantras above, the Arabic words assalamuallaiykum, Allah, bismillahirohmanirohim are found. Bismillahirohmanirohim and Allah are used in Islamic prayers. Both mantra have similar contents of asking the powerful and greater force than human (Allah; mbok ibu bumi [mother earth]; bapa kuwasa [the powerful "father"]) to help the people healing the diseases. Mantra is basically a form of prayer to the powerful supra natural force out there that the Javanese believe beyond human being's ability to comprehend. It shows how the mantra which can be said as the heritage of Hindu Buddhist belief is mixed with Islamic teaching.

This phenomenon also happened in Banjar Islamic community, South Kalimantan. Mantra has become a part of Banjar's old oral tradition since long time ago. This old oral tradition of in which later was named mantra after the coming of Budha and Siva beliefs has been started as a form of prayer to the greater power in Banjar's old belief, Kaharingan. Islam which came afterward has given a strong influence to Banjar community. Some Banjar Muslims also began to see that mantra practices were a form of syirik. However, Islam did not completely change the traditions in Banjar community since some traditional rituals still have been performed, including mantra practices. Banjar community then uses some Arabic words and Islamic praying in their mantra. This phenomenon is as a form of cultural compromise between old tradition of mantra with the Islamic teaching [12].

The influence of Islam becomes stronger in Sawangan District, Magelang Regency as some Islamic boarding schools such as Pondok Pesantren Gontor VI are run in that area [7]. Students from different places come to study there. The contact with other people outside the area then increases. The tourists, local and foreign, that visit the slope of Mt. Merapi-Merbabu for enjoying the view might also contribute to the exposure of the area with the visitors. They might give some influences to the local residents. With the fast paced communication and technologies development nowadays exchanging and distributing goods, message, news are easier. For example food found in a decent restaurant in Ketep Pass was fried bananas with cheese topping. Cheese is not common food found in that area. If uncommon food fills in the area the diet of the inhabitants might change also which effects their health. The illnesses are not only cold, cough, or fever anymore but diabetes, kidney, and even cancer are also found.

Some people who suffer from those illnesses also try to go to a dhukun to examine themselves. A dhukun as our informant admits that the treatment with regular mantra recitation he acquired from his ancestors is not sufficient enough to heal "modern" illness since those illnesses might not have existed or did not even exist when mantras were taught. He then tries to study the traditional treatment accompanied with mantra by rationalizing and making sense of it. He explains why some treatments use water and salt:

"Pasti ada media sendiri-sendiri. Lha itu minta air dan garam. Garam itu sebenarnya itu racun. Kalau orang ingin sehat jangan makan uyah. Kita jauh dari kolesterol, dari darah tinggi. Ketika orang dulu puasa mutih, itu pembakaran tubuh yang luar biasa [...] Kadang-kadang nyirik uyah, ora ketang sedina sewengi. Dalam sebulan sehari nggak makan garam."

(There must be its own medium in each mantra. (We) ask for a glass of water and salt. Salt is actually a poison. If you want to be healthy don't consume salt. It will get you away from cholesterol, from hypertension. Our elderly used to do "puasa mutih" (a 
fasting that is allowed to eat rice and drink water only). It is a good way to "burn" our body. It is better to avoid eating salt at least for one day, once in a month not consuming salt.)

Based on the statement above the media in traditional treatment such as a glass of water and salt that is usually recited with mantra before the patient drinks it is actually a detox to cleanse the body from bad poisonous substances.

The dhukun also explains that he uses plants that grow in their surrounding as traditional medicines. Here is how he treats diabetes:

[...] tau ning Tawangmangu tau ngombe kopi panas lambene nganti perih, awake malah adem. Lha aku tau kodanan malah nekat ngombe es, awake malah anget. Jebulane sing ning njero kulit lan awak iku pun menyatu dengan alam ora ngerasakke adem. Mangkane kula teng Dieng minum sing adem ora tau panas, dadi awake ora kademen. Saiki golekke tambane, loro gula niku napa to... dijajalke, yen gula ditambani nganggo gula sing asli, golekke badhek. Nira kelapa, nira aren. Atau siwalan, nanging sing deresan, bahan untuk gula. Karena dia manis steril, belum terkena radiasi apapun. Nah akhirnya sembuh.

([...] When I was in Tawangmangu I had ever drunk really hot coffee until my lips got burned but my body was cold. I've ever caught in a rain but I drank iced (tea), my body was warm. It is because what is inside our body and skin is blended with nature so we don't feel cold. Therefore whenever I am in Dieng, I always drink cold beverages. I never drink hot ones. Now find a cure for diabetes. ...Let's try. If it is sugar then give original sugar, find badhek...coconut or palm sap, an ingredient to make (coconut/palm) sugar, because its sweetness is sterile, hasn't got any radiation. And he finally healed.)

He observes and studies natural phenomena, how things in nature work, and tries to apply the result of his observation and study to give medical treatment. He argues that everything that is natural is much better than chemical materials since chemical materials will stay in our body. They are not easily released through sweat or urine. Below is an example of how he takes the plants characteristic to heal a broken leg.

Nek wong tugel sikile, lalu bagaimana menyambungnya, saya beri obat suruh tujuh lembar... karo godhong kacangan, sing wonten lunge. Bangsa tanaman merambat. Saya ramu dengan minyak kelapa dan garam agar meresap. Fungsinya daun kacang dan lung itu merambat biar menyambung balunge. Suruh juga (sebagai antibiotik). Mari ki, Pak... dongane ngene, mengko tirokno, diusapke turun dan naik, dari atas ke bawah, kemudian dari atas ke bawah. Menurut saya kalau arah turun kan membuang racun, kalau naik memasukkan [obat] ke pori-pori. Ono mantrane, mesthi, wulu pedhot, karena kalau patah itu pasti dari dalam sampai luar, wulu pedhot, tum-tumo wulu pedhot, kulit pedhot, tum-tumo kulit pedhot, daging pedhot, tum-tumo daging pedhot, bayu pedhot, tum-tumo bayu pedhot, otot pedhot, tum-tumo otot pedhot, balung pedhot, tum-tumo balung pedhot, sum-sum pedhot, tum-tumo sum-sum pedhot, karena tujuh lapisan. Menika ingkang awal, teruse saking lebet, diwalik malih sum-sum pedhot, tum-tumo sum-sum pedhot, ngantos dumugi wulu. Kaping tiganipun nggih saking wulu dumugi sum-sum.

(If a person breaks his leg, how to connect it again?, I give him seven betel leaves, bean leaves, any vines plants. I mix them with coconut oil and salt. Bean leaves are vines so that the bone can be like that plant, reconnect again with another bone. Betel leaves are 
for antibiotics. He healed. Here is the mantra, please repeat after me, rub that broken bone down and up, from top to bottom, then bottom to up. In my opinion, if you go down, you will get rid of the poison. If you go up, you get [medicine] into the pores. There's a mantra for it starting from mentioning the hair [leg] since if it is broken it is from the inside layer to the outer one: wulu pedhot, tum-tumo wulu pedhot, kulit pedhot, tum-tumo kulit pedhot, daging pedhot, tum-tumo daging pedhot, bayu pedhot, tum-tumo bayu pedhot, otot pedhot, tum-tumo otot pedhot, balung pedhot, tum-tumo balung pedhot, sum-sum pedhot, tum-tumo sum-sum pedhot, because there are seven layers [of the leg]. This is the first recitation then followed by the second recitation starting from the last one "sum-sum pedhot, tum-tumo sum-sum pedhot." The third one is from the hair to the marrow.)

When he was asked how significant the role of the mantra in medical treatment was, he mentioned that mantra worked as a motivation or encouragement for them to heal. A mantra is like a prayer. By reciting mantras, the Javanese believe that something powerful or greater outside themselves is able to help them heal [13].

\section{Conclusion}

In the discussion above it can be seen that the mantra practices for medical treatment in Sawangan District, Magelang Regency face some "challenges" as the fast paced changing occur in the area. The coming of Islam has given influence to the mantra which becomes Hindu Budhist heritage. As the understanding of Islamic belief increases some people consider the practice of mantra as syirik. However, for those who still practice it then insert some Islamic words or sometimes prayer in the mantra. Mantra then can be found as having Bismillahirohmanirohim in the beginning of the mantra recitation. It can be seen how cultural compromise occurs in the practice of mantra. Dhukun as mantra practitioner is also challenged by illnesses that have never been treated before. By rationalizing and making sense of mantra with knowledge the dhukun tries to treat the illnesses and succeed.

\section{References}

[1] K. Saddhono and A. Hartarta, "The Study of Type and Meaning of Javanese Indonesian Spell Language," Asien Dronar Ohosossearu Synesis Anado Hiumenites, vol. 2, no. 1, pp. 51-58, 2013.

[2] B. Wiratmojo, "Mantra Pengobatan di Desa Gantang Kecamatan Magelang (Kajian Struktur dan Fungsi)," Universitas Sebelas Maret, 2015.

[3] W. Widodo, "Mantra Kidung Jawa," Universitas Sebelas Maret, 2012.

[4] W. Widodo, Sumarlam, and Sudaryanto, "Mantra Kidung Jawa: Perangkat Linguistik dan Kemanjuran," TransLing J. Transl. Linguist., vol. 1, no. 1, pp. 65-75, 2013.

[5] B. Muhazetty, "Mantra Dalam Budaya Jawa (Suntingan Teks Ajian Jawa dan Kajian Pragmatik)," Diponegoro University, 2017.

[6] K. P. Kusciati, T. Widiastuti, and S. T. Widodo, "Spell for Your Health: Mantra Practiced in the Slope of Mt. Merapi and Mt. Merbabu," in Proceeding: International Conference on Humanities, Economy, and Technology (ICHET, 2018), 2018, no. November, pp. 152-157.

[7] A. Wibowo, "Islam di Lereng Merapi-Merbabu," 2017.

[8] K. Setyawati, "Mantra Pada Koleksi Naskah Merapi-Merbabu,” vol. 18, no. 1, pp. 63-71, 2006. 
[9] B. L. Berg, Qualitative Research Methods for The Social Sciences, 4th ed. Boston: Allyn and Bacon, 2001.

[10] J. Stokes, How To Do Media and Cultural Studies. London: Sage Publications, 2003.

[11] M. B. Miles and A. M. Huberman, Qualitative Data Analysis, 2nd ed. London: Sage Publications, 1994.

[12] A. Yulianto, "Mantra Banjar: Suatu Kompromi Budaya," Naditira Widya, vol. 5, no. 2, p. 133, 2016. 